\title{
Working Capital Management in the Process of Financial Support of the "Green Building" Projects
}

\author{
Anatoliy Trebukhin ${ }^{1, *}$ and Zhanna Lemesheva ${ }^{2}$ \\ ${ }^{1}$ Moscow State University of Civil Engineering, 26, Yaroslavskoye shosse, Moscow, 129337, Russia \\ ${ }^{2}$ Capital Finance and humanitarian Academy, 90/17, Shosseinaya Street, Moscow, 109383, Russia
}

\begin{abstract}
The article presents analysis of working capital in the financial support of the "green building" projects, factors which influence the choice of working capital management model were analyzed, reasons for changes in necessity of current assets values in the process of construction. Scheme of interconnections of manufacturing, operational and financial activity cycles of enterprises, which implementing the "green building" projects was developed and comparative characteristics of the sources of their funding was performed.
\end{abstract}

\section{Introduction}

Company needs to buy raw materials, materials, construction, etc. to carry out the manufacturing process. Business unit must accumulate certain amounts of finished "green building" projects for continuity of the realization process.

Calculations for the finished product is removed from circulation funds, creating receivables sometimes.

With liquidity maintenance purposes, company can place temporarily free funds in various short-term investments, which must have high liquidity and transform back into cash freely.

Availability of own working capital of the company, its composition and structure, turnover rate and efficiency of working capital usage are largely determining the state of company and stability of its position in the financial market [1-10].

\section{Methods}

Selection of working capital financing model depends on the objective factors, which are the value of financial and operational leverage.

The essence of these factors is clearly presented in Table 1 [2].

* Corresponding author: licence05@list.ru 
Table 1. Factors influencing the choice of working capital management model

\begin{tabular}{|l|l|}
\hline \multicolumn{1}{|c|}{ Financial leverage } & \multicolumn{1}{|c|}{ Operating leverage } \\
\hline $\begin{array}{l}\text { Increase in mass of the working capital at the } \\
\text { expense of the borrowing costs usage: }\end{array}$ & $\begin{array}{l}\text { Increase of the fixed costs at the amount } \\
\text { paid per cent: }\end{array}$ \\
$-\quad$ ability to increase the scope of activity or & $-\quad$ reduction of profitability; \\
avoid its reduction in the result of the lack of & - decrease of the risk at the expense of \\
working capital; & $\begin{array}{l}\text { breakeven point (breakeven) displacement } \\
-\quad \text { decrease of the risk at the expense of } \\
\text { to the left; }\end{array}$ \\
$\begin{array}{l}\text { breakeven point (breakeven) displacement to the } \\
\text { right; }\end{array}$ & \\
$-\quad$ increase in profitability of the own working \\
capital
\end{tabular}

S. Ross, R. Westerfield and B. Jordan [3] offer to analyze the following factors for selection rationale of the amount of short-term loan for the financing of the "green building" projects:

- cash reserves. Flexible fiscal policy presupposes the existence of the money surplus and small short-term loans. This policy reduces the probability of the financial hunger for the company.

- urgency insurance. Most companies are looking for the assets and liabilities urgency interconnection. They finance resources with short-term bank loans and the permanent assets with long-term financing. Companies try to avoid financing of the long-term assets through the short-term loans. This urgent payments confusion makes often refunding necessary and is risky as short-term interests are more volatile than the long-term rates.

- relative interest rates. Short-term interest rates are usually lower than the long-term ones. It means that generally its less profitable to resort to the long-term loans than the short ones.

In addition, at the selection of financial support it must be considered that company's need for working capital is not a constant value. Among the following [4]:

- scaling operations when the investments in fixed assets must comply with additional investments in working capital

- market strategy of the company;

- excessive diversion of funds in receivables;

- changes in the conditions of supply factors of manufacture and production

- necessity to replenish working capital, corroded by inflation.

- seasonal fluctuations in requirements of working capital, characteristic for a number of industries

- changes in market conditions, for which the company must respond flexibly by increasing of the amount of sales, which requires a corresponding change in the value of the applicable working capital (trade cycles) are short-term;

Such important characteristics as indicators of duration of operation and financial cycles are recommended to use for effectiveness of the chosen model and its financing [5].

Operating cycle (operating cycle) is the conventional name of the period, typical regular element of the commercial process (from receipt of raw materials to refund return of funds in the form of revenue), in duration of which funds in inventories and calculations (debtors) are deadened. Analytical index, which marks the average time of deadening of funds in these assets is called the length of the operating cycle (operating cycle period) and is calculated by the formula [6]:

$$
D_{O C}=I n v_{d}+A R_{d},
$$

where $\mathrm{D}_{\mathrm{OC}}$ - is the duration of the operating cycle in days; Invd - is inventory turnover in days; ${ }_{\text {ARd }}$ - is turnover funds in days. 
Financial cycle (cash cycle) is a conventional name of the period of the period, typical regular element of the commercial and technological process that begins with the funds actually go to the payment for suppliers for purchased raw materials and at the end of which funds are returned to the form of revenue. Indicator, which marks average time between actual cash outflow in connection with the implementation of current operations and their actual influx as a result of production and financial activities, called the financial cycle duration (cash cycle period) and is calculated as follows:

$$
D_{C C}=\operatorname{In} v_{d}+A R_{d}-A P_{d}
$$
days.

where $\mathrm{D}_{\mathrm{OC}}$ - is the duration of the finance cycle in days; $\mathrm{APd}^{-}$is creditor days' ratio in

Thus, the operational and financial cycle linked via circulation period of accounts payable. Such interrelation can be represented demonstrably as a Figure 1 [7].

Sense of the financial cycle is that effectiveness of financing activity of the company in a part of calculation of value with contractors is characterized not only by timeliness of claim of the accounts receivable, but a sound policy concerning creditors.

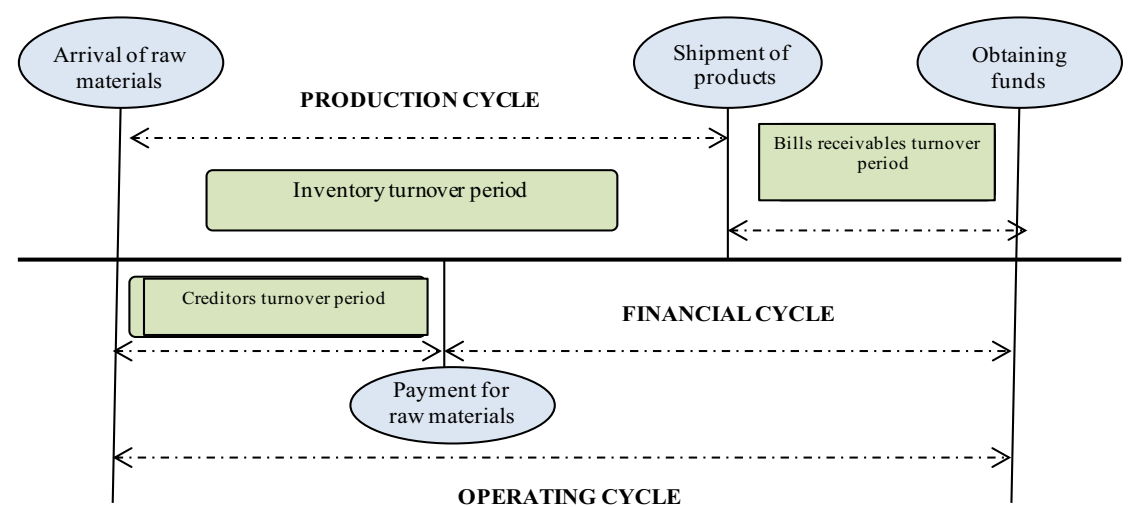

Fig. 1. Cluster diagram of the production, operational and financial cycles

Receivables and payables are mutually balance each other and their combined effect on the efficiency of cash circulation is expressed in the duration of the financial cycle [8].

\section{Results}

Deserves to be noted that any company is self-sustaining or self-financing system, which should provide a profitable job. In this connection sources of financing of the company, each of which has specific advantages and disadvantages (table 2) get paramount importance.

Table 2. Comparative characteristics of the "green building" projects sources of financing

\begin{tabular}{|l|l|l|}
\hline \multicolumn{1}{|c|}{$\begin{array}{c}\text { Sources of } \\
\text { financing }\end{array}$} & \multicolumn{1}{|c|}{ Dignities } & \multicolumn{1}{|c|}{ Disadvantages } \\
\hline $\begin{array}{l}\text { Internal } \\
\text { sources } \\
\text { (equity) }\end{array}$ & $\begin{array}{l}\text { 1. Ease, accessibility and speed of } \\
\text { mobilization. } \\
\text { 2. Reducing the risk of insolvency } \\
\text { and bankruptcy. } \\
\text { 3. Higher profitability in connection }\end{array}$ & $\begin{array}{l}\text { 1. Limitation of the fund attraction } \\
\text { amounts. } \\
\text { 2. Distraction of own funds from the } \\
\text { economic turnover. } \\
\text { 3. Limitation of independent monitoring }\end{array}$ \\
\hline
\end{tabular}




\begin{tabular}{|c|c|c|}
\hline & $\begin{array}{l}\text { with the lack of necessary payments } \\
\text { on attracted and borrowed sources. }\end{array}$ & for resource usage efficiency \\
\hline $\begin{array}{l}\text { External } \\
\text { sources } \\
\text { (attracted and } \\
\text { borrowed } \\
\text { capital) }\end{array}$ & $\begin{array}{l}\text { 1. Probability to attract funds in } \\
\text { significant scales. } \\
\text { 2. Presence of independent } \\
\text { monitoring for resource usage } \\
\text { efficiency }\end{array}$ & $\begin{array}{l}\text { 1. Complexity and duration of the } \\
\text { financial borrowing process. } \\
\text { 2. Necessity to provide guarantees of } \\
\text { financial stability. } \\
\text { 3. Reducing the risk of insolvency and } \\
\text { bankruptcy. } \\
\text { 3. Reduction of profitability in connection } \\
\text { with the lack of necessary payments on } \\
\text { attracted and borrowed sources. }\end{array}$ \\
\hline
\end{tabular}

\section{Discussions}

Hence it appears that management of the company must have a clear idea of what methods and at the expense of what resources they will perform their activity and in which business segments to invest their capital. So much attention is paid to the analysis of the financial state of the company, for which economic methods shown in the Picture 2 are applied.

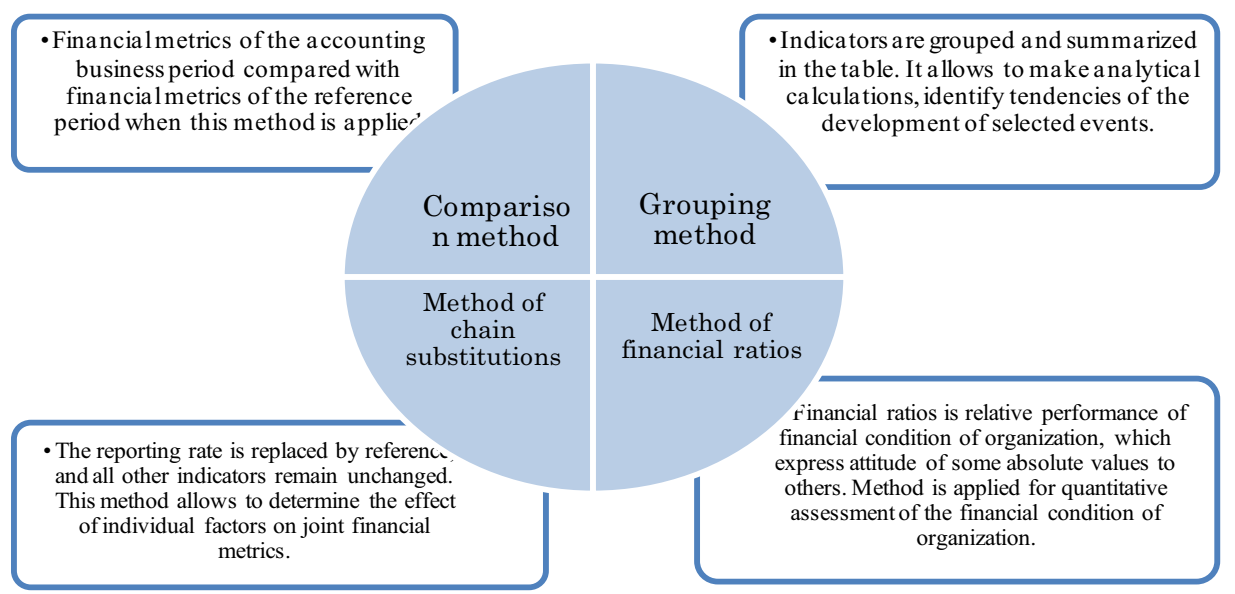

Fig. 2. Methods applied in financial analysis

\section{Conclusion}

So comparison of different methods of generating financial sources for "green building" projects allows company select an optimal method to ensure their financial activities and cover capital expenditures. The Company's finances are formed at the expense of certain sources. So, it is impossible to acquire production equipment, raw materials or materials, without money on this, so many companies use external sources in their management policies. Sources of formation of the financial resources of the company is the collection of sources of satisfaction of need for the capital for the forthcoming period providing development of the company.

\section{References}

1. N. Aktas, E. Croci, D. Petmezas. Journal of Corporate Finance, 30, 98-113 (2015) 
2. R. Çelik, B. Bilen, Ö. Bilen. Procedia Economics and Finance, 38, 122-134 (2016)

3. D.N. Silka. World Applied Sciences Journal 31, 148-150 (2014)

4. V.S. Kanhva, G.A. Syzrancev. Ekonomika i predprinimatel'stvo. 4-1 (69-1), 856-859 (2016)

5. J. Enqvist, M. Graham, J. Nikkinen. Research in International Business and Finance, 32, 36-49 (2014)

6. S. Baños-Caballero, P. J. García-Teruel, P. Martínez-Solano. Journal of Business Research, 67 (3), 332-338 (2014)

7. V.S. Kanhva, S.V. Belyaeva. Ekonomika i predprinimatel'stvo. 5-1 (58-1), 449-451 (2015)

8. E.M. Kiseleva, M.L. Nekrasova, M.A., Mayorova, M.N. Rudenko, V.S. Kanhva. International Review of Management and Marketing. 6. 6. 95-103 (2016)

9. A. Milajić, D. Beljaković, V. Solovev, V. Murgul, Procedia Engineering, 165, 947-953 (2016)

10. N. Harmathy, V. Murgul, Procedia Engineering, 165, 1845-1852 (2016) 